\title{
Evaluation of myeloid metaplasia in canine mixed mammary tumors
}

\author{
Cecilia B Campos ${ }^{1}$, Patricia A Auler', Angelica C Bertagnolli', Enio Ferreira', Gustavo M Ribeiro², Ana PM Dias', \\ Liliane C Campos', Geovanni D Cassali ${ }^{*}$ \\ From São Paulo Advanced School of Comparative Oncology \\ Águas de São Pedro, Brazil. 30 September - 6 October 2012
}

\section{Background}

Mixed tumors are among the most frequent mammary neoplasms in female dogs. Some of these tumors present bone marrow associated with the newly formed osseous tissue, characteristic of myeloid metaplasia. Our aims were to evaluate the occurrence of these lesions in a series of mixed tumors, and to determine tumor histomorphological characteristics.

\section{Materials and methods}

384 mammary mixed tumors from 289 animals have been reviewed. Lesions were classified according to the presence of osseous metaplasia associated with myeloid metaplasia or extramedullary hematopoiesis. Myeloid metaplasia characterization was determined from the morphological characteristics and organization of cells and adjacent tissues.

\section{Results}

The 384 cases included 206 benign and 178 carcinomas in mixed tumors. Osseous metaplasia was present in $16.1 \%$ and calcified areas exclusively in $3.1 \%$ of lesions. Among all osseous metaplasia, $33.9 \%$ presented some type of extramedullary hematopoiesis, of which $71.4 \%$ were classified as myeloid metaplasia and $28.6 \%$ as extramedullary hematopoiesis. Myeloid metaplasia cases consisted of $67 \%$ benign mixed tumors and 33\% carcinomas in mixed tumors. Myeloid metaplasia was observed in $24 \%$ of mixed tumors containing osseous metaplasia and in $4 \%$ of all mixed tumors analyzed.

\footnotetext{
* Correspondence: cassalig@icb.ufmg.br

'Department of General Pathology, Federal University of Minas Gerais (UFMG), Belo Horizonte, Brazil

Full list of author information is available at the end of the article
}

\section{Conclusions}

Despite these results and considering the low frequency of this lesion, additional studies are needed to understand the implications of myeloid metaplasia in canine mammary mixed tumors.

\section{Financial support \\ FAPEMIG, CAPES and CNPq.}

\section{Author details}

${ }^{1}$ Department of General Pathology, Federal University of Minas Gerais (UFMG), Belo Horizonte, Brazil. ${ }^{2}$ Department of Medical Sciences, Federal University of Ouro Preto (UFOP), Ouro Preto, Brazil.

Published: 4 April 2013

doi:10.1186/1753-6561-7-S2-P13

Cite this article as: Campos et al:: Evaluation of myeloid metaplasia in canine mixed mammary tumors. BMC Proceedings 2013 7(Suppl 2):P13.

Submit your next manuscript to BioMed Central and take full advantage of:

- Convenient online submission

- Thorough peer review

- No space constraints or color figure charges

- Immediate publication on acceptance

- Inclusion in PubMed, CAS, Scopus and Google Scholar

- Research which is freely available for redistribution

Submit your manuscript at www.biomedcentral.com/submit
() Biomed Central

\section{Biomed Central}

